\title{
Analysis of the effect of methadone and temperature on the development rate of Calliphora vicina (Diptera: Calliphoridae): A forensically important fly
}

\author{
DAWOUD KESHAVARZI ${ }^{1}$, YAVAR RASSI ${ }^{1, \vartheta}$, KOUROSH AZIZI ${ }^{2}$, MOHAMMAD ALI OSHAGHI ${ }^{1}$, \\ SAYENA RAFIZADEH ${ }^{3}$, ALI MOHAMMAD ALIMOHAMMADI ${ }^{4}$, MARZIEA SHAHRIARI NAMADI ${ }^{2}$, \\ SEYEDEH ZAHRA PARKHIDEH ${ }^{1}$ \\ ${ }^{1}$ Department of Medical Entomology and Vector Control, School of Public Health, Tehran University of Medical Sciences. Tehran, Iran. \\ vemail: rassi184@gmail.com, fereidoonim25@gmail.com \\ ${ }^{2}$ Research Center for Health Sciences, Institute of Health, Department of Medical Entomology and Vector Control, School of Health, Shiraz University of \\ Medical Sciences. Shiraz, Iran \\ ${ }^{3}$ Ministry of Health and Medical Education. Tehran, Iran \\ ${ }^{4}$ Tehran Legal Medicine Organization. Tehran, Iran
}

Manuscript received: 5 July 2020. Revision accepted: 11 August 2020.

\begin{abstract}
Keshavarzi D, Rassi Y, Azizi K, Oshaghi MA, Rafizadeh S, Alimohammadi AM, Namadi MS, Parkhideh SZ. 2020. Analysis of the effect of methadone and temperature on the development rate of Calliphora vicina (Diptera: Calliphoridae): A forensically important fly. Nusantara Bioscience 12: 87-91. The development rate/time of flies is a scientific method to estimate the minimum time elapsed after death. Several studies have shown that opioids and temperature affect maggot growth rates. However, there are few published data that investigate the effect of ante-mortem methadone use on larval length of Calliphora vicina (Robineau-Desvoidy). Therefore, the purpose of this research was to investigate the effect of methadone and temperature on the development rate/time of this species. During this study, four rabbits were administered $0.10,0.50,1.0$, and $10 \mathrm{mg} / \mathrm{kg}$ of methadone via gavage over a period of 14 days, and a five rabbit, which did not receive methadone, was used as a control. The rabbits' tissues were separated and exposed to maggots for rearing. Minimum developmental times of $C$. vicina life stages at six constant temperature regimes were provided. From hours 48 to 96 , larvae feeding on tissues containing $10 \mathrm{mg} / \mathrm{kg}$ methadone developed more rapidly than those feeding on tissues containing $0.1,0.50$, and $1 \mathrm{mg} / \mathrm{kg}$ and also from the control. In the present study, development rate of $C$. vicina was linearly related to temperature $(\mathrm{R} 2=0.96, \mathrm{p}=0.02)$ between 16 and $32^{\circ} \mathrm{C}$. The results revealed that the differences observed in the rates of development were sufficient to alter postmortem interval estimates based on larval development by up to $24 \mathrm{~h}$.
\end{abstract}

Keywords: Forensic entomology, insect development rate/time, methadone

\section{INTRODUCTION}

Synthetic opioid deaths continue to rise in different parts of the world (Akhgari et al. 2018; Concheiro-Guisan et al. 2018). There are more than 42,000 deaths due to opioid overdose in the United States (Concheiro-Guisan et al. 2018). Methadone is a synthetic opioid drug with a high attraction to $\mu$ receptors that prescribed for the treatment of opioid addiction (Hsieh et al. 2018; Wolff 2002). This is a widely used drug in Iran and 1274 related deaths were reported from Tehran during 2009-2015 (Akhgari et al. 2018).

Forensic entomotoxicology, as a new branch of forensic entomology, studies the use of insects as alternate toxicological specimens and the effects of drugs on insect physiology (Fathy et al. 2008; Amendt et al. 2007). Necrophagous species include dipteran and coleopteran species are the most important orders for PMI determination in different stages of decomposition (Watson 2004). The degree of development of insects is the main technique for estimating PMI. In this technique, the investigator calculating the maggot age by measurement of the larval length, actually the maggot age indicates the time when flies first laid their eggs on the cadaver (Amendt et al. 2007; Fathy et al. 2008). The ages of maggots found on a corpse can provide evidence for the estimation of a minimum PMI ranging from $24 \mathrm{hr}$. up to more than 5 weeks, depending on the fly species involved and the climatic conditions at the death scene (Donovan et al. 2006). Flies are ectothermic and they are thus specifically susceptible to climatic changes. Development rates are affected by weather conditions, temperature, relative humidity, food sources, body decomposition stage, and the presence of drugs in the tissues as food (Mann et al. 1990; Turchetto and Vanin 2004).

Some species of calliphorid flies are attracted to carcasses of animals (Keshavarzi et al. 2019). The imago will feed on any secretions, including blood, and gravid females will rapidly lay their eggs on the body. In the case of Calliphora vicina (Robineau-Desvoidy) as a cold friend species, at temperatures between $14-16^{\circ} \mathrm{C}$ the eggs hatched after about $24 \mathrm{~h}$, whereupon the larvae begin to feed on the body tissues. After growth is complete, the post-feeding larvae usually migrate away from the remainder to pupariate (Hans et al.2019; Ody et al. 2017). Calliphora vicina is widely distributed throughout Middle East as well 
as in Iran (Akbarzadeh et al. 2015), so, it is important to study the life cycle of this species.

The effects of drug/toxin on body weight and body length as well as the rate of development of insects have been investigated in several, for example; heroin, codeine, and methamphetamine decrease larval development time and increase the larval length (Fathy et al. 2008; Goff et al. 1991; Goff et al. 1997). In most above-mentioned studies, the animal model was killed immediately after the substance injection. But in the present study, the animal becomes addicted to the substance and exposure to the substance for a longer period of time. Hence, the current study described here attempts to determine whether antemortem use of methadone impact on the development rate of C. vicina, and also examined the larval length of this species at temperatures of between $15^{\circ} \mathrm{C}$ and $32^{\circ} \mathrm{C}$, under controlled laboratory conditions.

\section{MATERIALS AND METHODS}

\section{Study sites}

The study was conducted in winter 2019 in the Research Station of Kazerun $\left(29^{\circ} 37^{\prime} 10^{\prime \prime} \mathrm{N} 51^{\circ} 39^{\prime} 15^{\prime \prime} \mathrm{E}\right)$, a research facility of Tehran University of Medical Sciences located in the county town of Kazerun, Fars Province, southern Iran. Kazerun is $860 \mathrm{~m}$ above sea level and the climate in the region is a subtropical steppe type with an average annual temperature of $21.6^{\circ} \mathrm{C}$ and precipitation rate of $257 \mathrm{~mm}$.

\section{Carcasses and methadone dosing}

Four rabbits $(\approx 1.8-2.3 \mathrm{~kg})$ obtained from the Animal Lab at Shiraz University. Four animals were administered methadone before euthanasia and one was used as controls. Trial rabbits received $0.10,0.50$, and $10 \mathrm{mg} / \mathrm{kg} /$ day of methadone via gavage over a period of 14 days. At the end of the period, blood samples were taken from the ear vein of rabbits and were analyzed for methadone by one step methadone test stripe (Abon ${ }^{\circledR}$, China) At the end of the treatment period, the animals were killed by chloroform $(2$ $\mathrm{ml} / \mathrm{kg}$ ) and their tissues were separated and exposed to $C$. vicina larvae for rearing. The Ethical Committee of the Tehran University of Medical Sciences, Iran has granted permission to use rabbits as a research animal for this study.

\section{Source of larvae and rearing}

Adults of $C$. vicina were collected from chicken liver in the county town of Kazerun. Adults were identified using morphological character described by Akbarzadeh et al. (2015). The flies were held in an insectarium at $22{ }^{\circ} \mathrm{C}+/-2$ with $60 \%$ relative humidity and a photoperiod of LD 16:8 h. About 85 flies were kept in a net $(40 \mathrm{~cm} * 40 \mathrm{~cm} * 40$ $\mathrm{cm}$ ) and fed with water, sugar, and also rabbit blood to allow egg maturation (Figure 1). After the oviposition, eggs were transferred into 3 plastic jars $(12 * 15 * 22 \mathrm{~cm})$ containing rabbit tissues with different methadone concentrations. This procedure was repeated 3 times for each concentration. The bottom of each jar was covered with $2 \mathrm{~cm}$ thick sawdust, to provide a dry place for pupation. Few drops of water were sprayed daily to keep the substrates moist. Following hatching, 15 larvae at each growth stage were randomly selected from each plastic container and fixed in boiling water for 3 minutes, and then maintained in $70 \%$ alcohol and their lengths measured within $1 \mathrm{~h}$ using a ruler and also an eyepiece micrometer on a light microscope. The developmental time/rate was monitored every $12 \mathrm{~h}$ during photoperiod.

\section{Growth under different constant temperature regimes}

Fresh rabbit tissues were provided as a suitable source for oviposition at $22^{\circ} \mathrm{C}$. The oviposition time was recorded, and eggs were removed and transferred into plastic jars. The jars were then placed into a precision incubator at one of six desired temperature regimes $\left(16,20,24,28,32^{\circ} \mathrm{C}\right)$. This procedure was repeated three times for each temperature regime $(n=3)$, and approximately 200 eggs were used in each replicate. Larval length in each temperature regime measured as mentioned before. Lower temperature threshold for development was estimated from the linear regression of the developmental rates $(y=$ 1/developmental time) on constant temperature (x) (Campbell et al. 1974).

Statistical analysis of the data was conducted using SPSS v12.0.1 and a $p$ value $\leq 0.05$ was considered significant for all of the following analyses. Data normality was inspected using Kolmogorov-Smirnov normality tests. One-way ANOVA test was used to investigate differences between treatment groups.

\section{RESULTS AND DISCUSSION}

The mean time of development from oviposition to pupariation and from oviposition to adult eclosion at each of the six studied temperature regimes is specified in Table 1. We observed that few eggs hatched at $32^{\circ} \mathrm{C}$ and development time was not completed at $32^{\circ} \mathrm{C}$ and all pupae died. The rate of maggot development (from oviposition to pupariation) increased with temperature, with development rates of $0.08,0.12,0.14,0.16$, and 0.20 , at $16,20,24,28$, and $32{ }^{\circ} \mathrm{C}$, respectively. In the present study, development rate of $C$. vicina was linearly related to temperature $(\mathrm{R} 2=$ $0.96, p=0.02$ ) between 16 and $32^{\circ} \mathrm{C}$. The lower threshold temperature for this species was $1.8^{\circ} \mathrm{C}$. The mean larval length from first instar to pupariation at each of the six studied temperature regimes is provided in Figure 2. The duration of each developmental stage under all temperature regimes provided in Figure 3.

Table 1. Average developmental times of C. vicina life stages at five constant temperature regimes.

\begin{tabular}{lcc}
\hline Temperature $\left({ }^{\circ} \mathbf{C}\right)$ & $\begin{array}{c}\text { Days from oviposition to: } \\
\text { Pupariation }\end{array}$ & Emergence \\
\hline 16 & $12.5+/-0.10$ & $29.7+/-0.36$ \\
20 & $8.2+/-0.12$ & $19.8+/-0.21$ \\
24 & $7.0+/-0.28$ & $16.2+/-0.24$ \\
28 & $6.2+/-0.18$ & $15.0+/-0.40$ \\
$32 *$ & $5.1+/-0.13$ & Not emerged \\
\hline
\end{tabular}



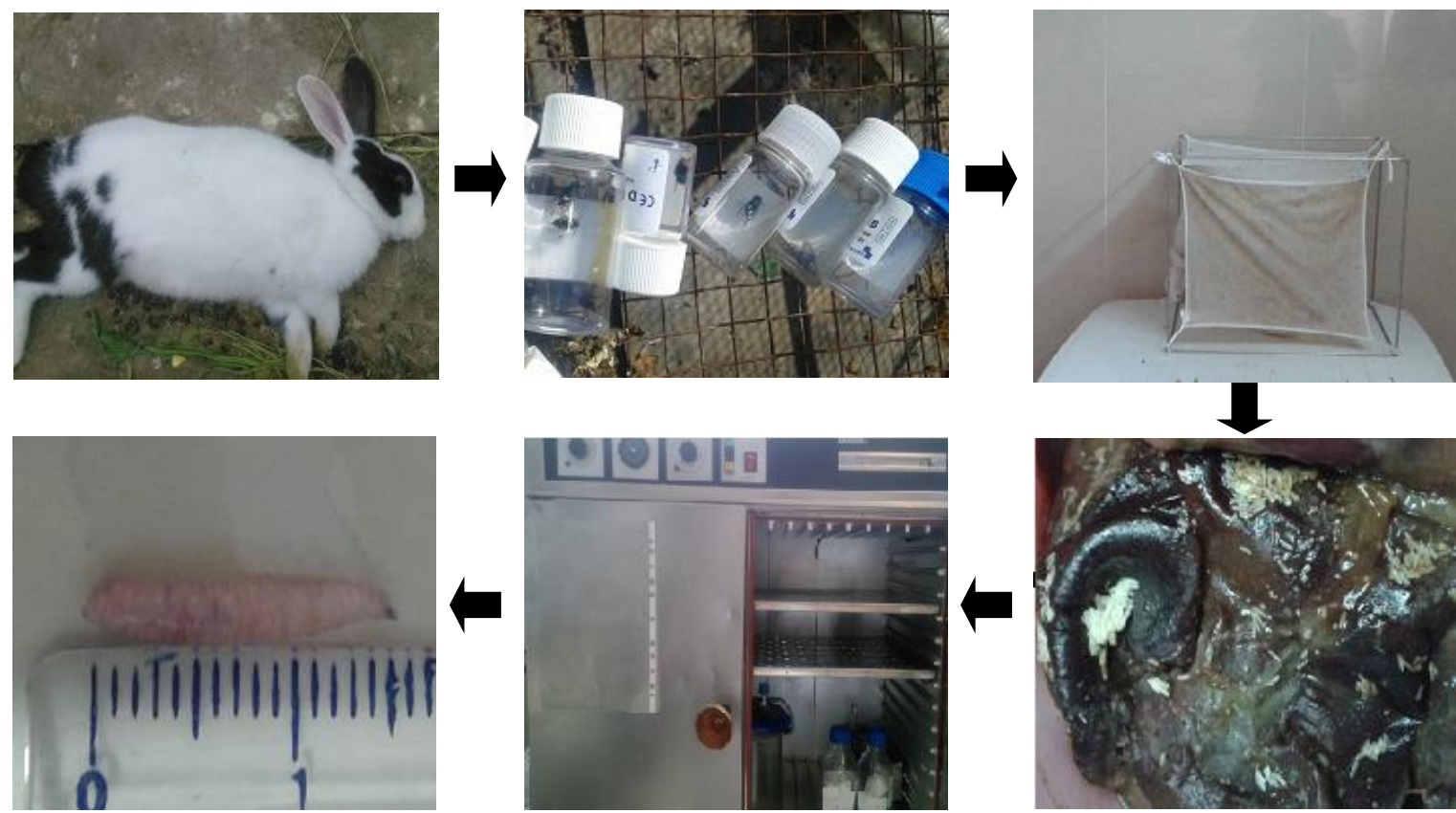

Figure 1. Sampling process, rearing and measuring of the larval length

In the present study, from hours 48 to 96 , larvae feeding on tissues containing $10 \mathrm{mg} / \mathrm{kg}$ methadone developed more rapidly than those feeding on tissues containing $0.1,0.50$ and $1.0 \mathrm{mg} / \mathrm{kg}$ and also from the control. The mean larval length from first instar to pupariation in each of the four studied treatments is given in Figure 4. One-way ANOVAs showed no statistically significant differences between the first three concentrations $(0.1,0.50$, and $1 \mathrm{mg} / \mathrm{kg})$ in length $(\mathrm{p}=0.21)$. While, larvae feeding on tissues containing 10 $\mathrm{mg} / \mathrm{kg}$ methadone developed more rapidly than those feeding on tissues containing $0.1,0.50$, and $1 \mathrm{mg} / \mathrm{kg}$ and also from the control and this difference was statically significant $(\mathrm{p}=0.041)$.

With respect to larval growth rates, this study determined that the development of $C$. vicina is affected by methadone only in high concentrations. This finding is similar to a previous study that used different species and feeding substrates (Gosselin et al. 2011; Strehler 2008). Gosselin et al. (2011) identified methadone and its metabolite (EDDP) in Lucilia sericata pupae only at high concentrations $(8.4 \mu \mathrm{g} / \mathrm{g})$. The development time in the control group and low concentrations was similar, it could be related to the degradation power of methadone by C.vicina fat bodies (Gosselin et al. 2011). In another study, methadone increased the length of the larvae and reduced the overall development time by 15 hours (Hecht et al. 2007). Contrary to our study, Strehler et al. (2008) reported that methadone at concentrations of 0.5 and $0.1 \mathrm{mg} / \mathrm{kg}$ had a significant effect on $C$. vicina larval length on days 5 and 6 and reducing larval length.

The study conducted by George et al. (2009) showed that growth rates of Calliphora stygia fed on morphine spiked mince did not differ significantly from those fed on control mince. Another study on the effect of morphine in rabbit tissues on the rate of development of Lucilia sericata showed that morphine affects the growth rate of the species and reduces the length of the larvae and increases the duration of larval development. But it does not affect the length of the pupae. At doses of 12, 25, and $50 \mathrm{mg}$, morphine could change the estimated death time from 24 to 162 hours in rabbits (Bourel,1998). According to Goff et al. study (1991), heroin shortened the duration of the larval period. But it increases the length of the pupal period. Heroin was also negative in larvae fed on morphinecontaining tissue at 12 or $18 \mathrm{mg}$ concentrations in the first 24 hours of heroin testing, but it was positive at 48 hours. The results of our study revealed that the differences observed in the rates of development were sufficient to alter postmortem interval estimates based on larval development by up to $24 \mathrm{~h}$.

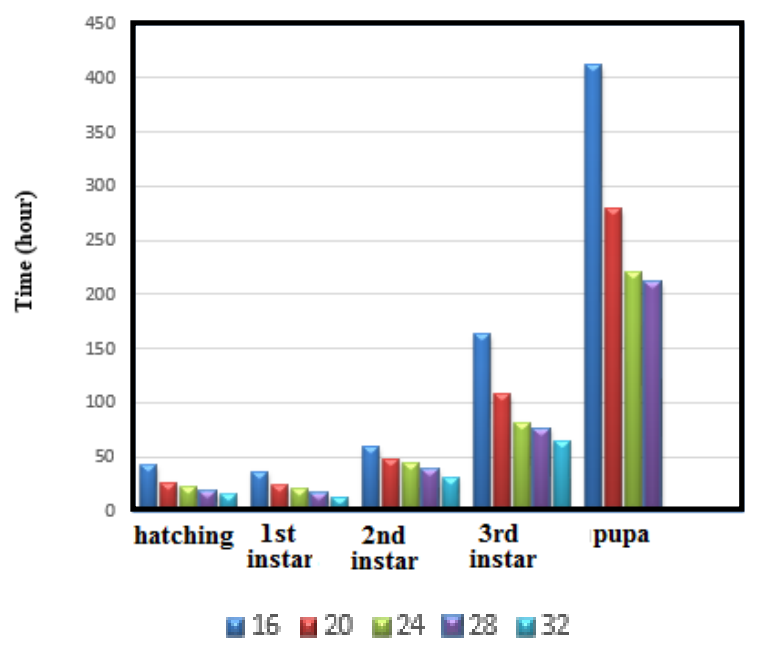

Figure 3. Development time of Calliphora vicina life stages from hatching to pupation at five different constant temperature regimes 


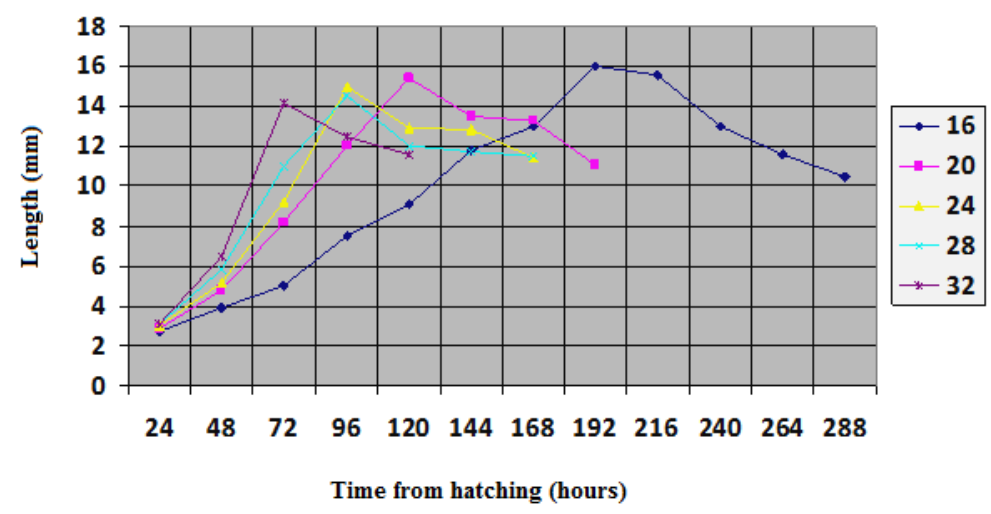

Figure 2 Average length of Calliphora vicina from hatching to pupation at five different constant temperature regimes.

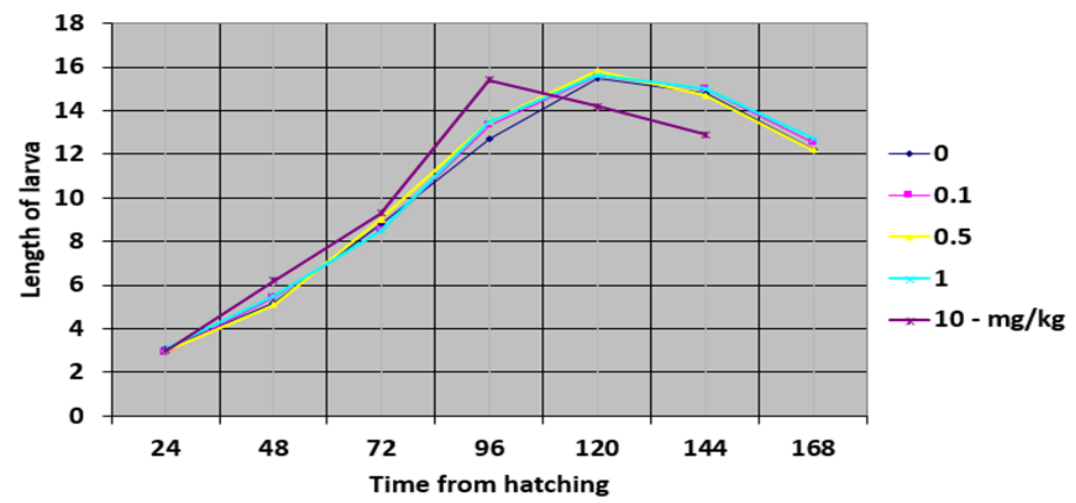

Figure 4. Average length of Calliphora vicina larvae at different concentration of methadone

In the present study, development of C. vicina was linearly related to temperature between 16 and $32^{\circ} \mathrm{C}$ and the lower threshold temperature was $1.8^{\circ} \mathrm{C}$. Marchenko (2001) reported that threshold temperature was $2^{\circ} \mathrm{C}$. In the present study, we observed that few eggs hatched at $32^{\circ} \mathrm{C}$ and development time was not completed at $32^{\circ} \mathrm{C}$ and all pupae died. It has been reported that the highest and lowest temperatures $\left(15^{\circ} \mathrm{C}\right.$ and $\left.28^{\circ} \mathrm{C}\right)$ had a deleterious effect on C. vicina (Defilippo et al. 2013).

In the present study, development time from oviposition to pupariation and to adult eclosion was similar to Defilippo et al. (2013) study. But this time was different from Marchenko study (2001), where, at $20^{\circ} \mathrm{C}$, development times from oviposition to pupariation were 10.5 and from oviposition to emergence was 21.6. While in this study, development times were 8.2 days for pupariation and 19 days for adult eclosion.

We conclude that the development time of $C$. vicina varied at different temperatures and high concentration of methadone could also reduce its development time. Therefore, the presence of this substance in high concentration in cadaver could have an effect on the PMI estimation based on the development time. The current study supplied a database in the field of medico-legal entomology, these data could be useful or estimating minimal postmortem intervals.

\section{ACKNOWLEDGEMENTS}

This paper is extracted from parts of the dissertation of DK in medical entomology of Tehran University of Medical Sciences, Tehran, Iran. The author(s) have received financial support from Tehran University of Medical Sciences, Project No. 38345. We would like to thank the Shiraz University of Medical Sciences, Iran for their kindly cooperation. This research was funded by Tehran University of Medical Science (Grant No. 38345).

\section{REFERENCES}

Akbarzadeh K, Wallman JF, Sulakova H, Szpila K, 2015. Species identification of Middle Eastern blowflies (Diptera: Calliphoridae) of forensic importance. Parasitol Res 114 (4); 1463-1472.

Akhgar M, Amini-Shirazi N, Iravani FS. 2018. Forensic Toxicology Perspectives of Methadone-associated Deaths in Tehran, Iran, a 7-year Overview. Basic Clin Pharmacol Toxicol 122 (4): 436-441.

Amendt J, Campobasso CP, Gaudry E, Reiter C. 2007. Best practice in forensic entomology - standards and guidelines. Intl J legal Medicine 121: $90-104$.

Bourel B, Hédouin V, Martin-Bouyer L, Bécart A, Tournel G, Deveaux M, Gosset D. 1999. Effects of morphine in decomposing bodies on the development of Lucilia sericata (Diptera: Calliphoridae). J Forensic Scie 44 (2): 354-358. 
Campbell A, Frazer BD, Gilbert N, Gutierrez AP, MacKauer M. 1974. Temperature requirements of some aphids and their parasites. J Appl Ecol 11: (2) 431-438.

Concheiro-Guisan M, Chesser R, Pardi J, Cooper G. 2018. Postmortem toxicology of new synthetic opioids. Front Pharmacol 9: 1210 :DOI 10.3389/fphar.2018.01210.

Defilippo F, Bonilauri P, Dottori M. 2013. Effect of temperature on six different developmental landmarks within the pupal stage of the forensically important blowfly Calliphora vicina (Robineau-Desvoidy)(Diptera: Calliphoridae). J Forensic Sci 58 (6): 1554-7.

Donovan SE, Hall MJ, Turner BD, Moncrieff CB. 2006. Larval growth rates of the blowfly, Calliphora vicina, over a range of temperatures. Medical Vet Entomol 20 (1): 106-14.

Fathy HM, Attia RA, Yones DA, Eldeek HE, Tolba ME, Shaheen MS. 2008. Effect of codeine phosphate on developmental stages of forensically important Calliphoridae fly: Chrysomya albiceps. Mansoura J Forensic Med Clin Toxicol 16 (1): 41-59.

Goff ML, Brown WA, Hewadikaram K, Omori A. 1991. Effect of heroin in decomposing tissues on the development rate of Boettcherisca peregrina (Diptera, Sarcophagidae) and implications of this effect on estimation of postmortem intervals using arthropod development patterns. J Forensic Sci 36: 537-542.

Goff ML, Miller ML, Paulson JD, Lord WD, Richards E, Omori AI. 1997. Effects of 3, 4-methylenedioxymethamphetamine in decomposing tissues on the development of Parasarcophaga ruficornis (Diptera: Sarcophagidae) and detection of the drug in postmortem blood, liver tissue, larvae, and puparia. J Forensic Sci 42: 276-280.

Gosselin M, Di Fazio V, Wille SM, Fernandez MD, Samyn N, Bourel B, Rasmont P. 2011 . Methadone determination in puparia and its effect on the development of Lucilia sericata (Diptera, Calliphoridae). Forensic Sci Intl 209 (1): 154-9.

Hecht L, Klotzbach H. 2007. Einfluss von Methadon auf die Entwicklung von Lucilia sericata. Rechtsmedizin 17: 83-88[Germany] .
Hans KR, LeBouthillier R, VanLaerhoven SL. 2019. Effect of temperature on oviposition behavior and egg load of blowflies (Diptera: Calliphoridae). J Med Entomol 56 (2): 441-7.

Hsieh A, DiGiorgio L, Fakunle M, Sadeghi-Nejad H. 2018. Management strategies in opioid abuse and sexual dysfunction: a review of opioidinduced androgen deficiency. Sexual Med Rev 6: 618-623.

Keshavarzi D, Zaimy M ,Yusuf MA, Shahriarinamadi M, Parkhideh S, 2019. Insect succession on carrion in Fars Province, southwestern Iran. Egyptian J Forensic Sci 9, 18-26.

Mann R, Bass W, Meadows L. 1990. Time since death and decomposition of the human body: variables and observations in case and experimental field studies. J. Forensic Sci 35: 103-111.

Marchenko MI. 2001. Medicolegal relevance of cadaver entomofauna for the determination of the time of death. Forensic Sci Int 120 (1-2): 89109.

Ody H, Bulling MT, Barnes KM. 2017. Effects of environmental temperature on oviposition behavior in three blowfly species of forensic importance. Forensic Sci Int 275: 138-143.

Strehler M, Klotzbach H, Madea B, Reibe S, 2008. Entwicklung von Calliphora vicina unter nahrungszugabe von methadon. Rechtsmedizin 18 425-430.

Sanyanga T. 2016. Entomological examination of the relationship between ante-mortem and post-mortem amitriptyline concentrations in insects. University of Cape Town, South Africa.

Turchetto M, Vanin S. 2004. Forensic entomology and climatic change. Forensic Sci Intl 146:S207-9.

Watson EJG. 2004. Faunal Succession of Necrophilous Insects Associated with High-Profile Wildlife Carcasses in Louisiana. [Dissertation]. Western Washington University, Bellingham, USA.

Wolff K. 2002. Characterization of methadone overdose: clinical considerations and scientific evidence. Ther Drug Monitor 24: 457470 . 